\title{
Sugarcane rind: applications and health benefits: a review
}

\author{
Yue Luo, Shiming Li and Chi-Tang Ho*
}

Department of Food Science, Rutgers University, New Brunswick, NJ 08901, USA

${ }^{*}$ Corresponding author: Chi-Tang Ho, Department of Food Science, Rutgers University, New Brunswick, NJ 08901, USA. E-mail: ctho@ sebs.rutgers.edu

DOI: $10.31665 /$ JFB.2018.3148

Received: July 13, 2018; Revised received \& accepted: September 03, 2018

Citation: Luo, Y., Li, S., and Ho, C.-T. (2018). Sugarcane rind: applications and health benefits: a review. J. Food Bioact. 3: 1-7.

\begin{abstract}
Sugarcane rind is usually treated as an industrial waste. However, it contains valuable phytochemicals that can be extracted and utilized. Herein we provide a comprehensive review about application and health benefits of the phytochemicals in sugarcane rind, including polyphenols, flavonoids, especially anthocyanins, phenolic acids, long chain fatty alcohols particularly 1-octacosanol, phytosterols and fiber. Various bioactivities are associated with these phytochemicals, such as antioxidant, anticancer, antivirus, inhibition of inflammatory, and attenuation of the risk of cardiovascular and coronary disease. However, further studies are warranted to focus on health benefits of sugarcane rind and to elucidate their action mechanisms.
\end{abstract}

Keywords: Sugarcane; Phytochemicals; Flavonoids; Biological activity; Sugarcane rind.

\section{Introduction}

Sugarcane (Saccharum officinarum), known for its high content of sucrose in its stem, is a crop indigenous to India and common in tropical and subtropical countries (DAFFRSA, 2014). Therefore, sugarcane is largely used in sugar production. Global sugar production for marketing year 2017/18 was estimated to reach a new record of 185 million metric tons, and Brazil, India, European Union, Thailand and China are the top five sugar producers (USDA, 2017 ). Around $80 \%$ of the world sugar production is from sugarcane and the remaining $20 \%$ is from sugar beet and palm (Nair, 2009). One hundred tons of sugarcane can roughly produce raw sugar, bagasse, filter cake, molasses and waste water as 14.3, 27.2, 5.2, 2.6 and 50.7 tons, respectively (Allen et al., 1997).

The outer layer of sugarcane stem may be called skin, peel, rind, or epidermis, among others. In sugar industry, sugarcane is usually directly squeezed to extract sucrose juice without peeling (AG, 2011). High yields of sugar would be obtained and shorter process time is needed if sugarcane was peeled first by abrasive tools and then squeezed (Songsermpong \& Ijttanit, 2010). The leftover sugarcane rind after sugar extraction is usually regarded as a waste material. However, plenty of phytochemicals exist in sugar rind such as flavonoids, phenolic acids, phytosterols and others that have not been investigated and utilized adequately for their potential values (Li et al., 2010).
Recent studies have shown that phytochemicals contained in sugarcane rind have significant health benefits such as antioxidant, anticancer, anti-tumor (Chu et al., 2016) and anti-fibrotic (Wang et al., 2018) properties. For instance, one study indicated the beneficial effects of sugarcane peel ethanolic extract on hematological and histopathological parameters of Wistar Albino rats. Decreased levels of white blood cells, packed cell volume, platelets and hemoglobin and degeneration of follicles were increased especially at high dose levels of the ethanolic extract of sugarcane peels (Ashade et al., 2014). The anti-fibrotic properties of sugarcane polyphenol extract have been proven by inhibition of $\mathrm{p} 38$ and JNK phosphorylation MAPK signaling pathways in $\mathrm{CCl}_{4}$ induced liverfibrosis rats (Wang et al., 2018).

Thus far, there has been little investigation in reusing sugarcane rind, underlying the actual profound values of sugarcane rind both in nutrition and economy. In this review, we aim to provide a comprehensive summary of composition and health benefits of phytochemicals in sugarcane rind, to draw more attention to sugarcane rind research and usage.

\section{Phytochemicals and bioactivity}

Sugarcane rind includes surface wax layer, thin colorful layer and 
Table 1. Major phenolic compounds in the sugarcane polyphenol extract ${ }^{\mathrm{a}}$

\begin{tabular}{llllll}
\hline Compound & Gallic acid & Catechin & Sinapic acid & Ferulic acid & (-)-Epicatechin \\
\hline Content $(\mathrm{mg} / \mathrm{g})$ & $0.50 \pm 0.04$ & $0.67 \pm 0.45$ & $1.66 \pm 0.01$ & $1.31 \pm 0.09$ & $27.24 \pm 1.48$ \\
\hline
\end{tabular}

aThe values are expressed as the mean \pm SD of triplicate tests.

inside thin pulp layer. Sugarcane wax can be easily and efficiently extracted from sugarcane rind (Partha \& Sivasubramanian, 2006). The yield of crude wax can reach up to $0.95 \%(\mathrm{w} / \mathrm{w})$ of dried sugarcane peels using supercritical $\mathrm{CO}_{2}$ extraction. Sugarcane wax is the major source of esters, alkanes, fatty acids and alcohols in sugarcane, from which the valuable ones include very long fatty alcohols and acids such as glycolic acid and policosanols, especially 1-octacosanol (1OC) (Inarkar \& Lele, 2012). Besides, polyphenols, including flavonoids (Pallavi et al., 2012), anthocyanins (Zhao et al., 2018) and phenolic acids (Feng et al., 2015b), dietary fibers (Zhuang et al., 2016) and phytosterols such as stigmasterol, campesterol and $\beta$-sitosterol (Georges et al., 2006) can be extracted from sugarcane rind.

\subsection{Overall polyphenols and associated bioactivity}

Polyphenols are natural phytochemicals in whole plant foods. Different categories are classified by the number of phenol rings and structural elements (Pietta et al., 2003). Flavonoids are the most abundant dietary polyphenols consisting of six subclasses, namely anthocyanins, flavonols, flavanols, flavanones, flavones and isoflavones. Phenolic acids in the diet include two main classes of hydroxybenzoic acid derivatives (protocatechuic acid, gallic acid, $p$-hydroxybenzoic acid) and hydroxycinnamic acid derivatives (caffeic acid, chlorogenic acid, coumaric acid, ferulic acid, sinapic acid) (Bahadoran et al., 2013). Polyphenols have been studied for decades, and enormous evidences showed that polyphenols had nutraceutical properties like antioxidant, anti-radical activity, anticarcinogenic, anti-atherosclerotic, anti-inflammatory, antimicrobial, antihyperglycemic, spasmolytic, antiviral, hepatoprotective, oestrogenic activity and inhibition of histamine release (Hanamura et al., 2006; Iwai, 2008; Pietta et al., 2003).

A recent study in colon cancer cell model showed that whole dried sugarcane (WDS) ethanol extract had large quantity of polyphenols, strong antioxidant and anti-inflammatory activity. WDS altered protein expression in NFKB pathway, suppressing the phosphorylation of NFKB and inhibiting secretion of the pro-inflammatory cytokine IL-8. Kinase enrichment analysis showed that CRaf played a role in controlling WDS activity in this mechanism (Bucio-Noble et al., 2018).

Sugarcane polyphenol extract (Table 1) showed potential anti-fibrotic activity by inhibiting p38 and JNK phosphorylation in MAPK signaling pathways in $\mathrm{CCl}_{4}$ induced liver-fibrosis rats. Prominent endogenous profibrotic growth factor TGF- $\beta 1$ contributes to liver fibrosis by activating hepatic stellate cells into myofibroblast like cells via p38, ERK and JNK signaling pathways, and activated myofibroblast like cells will successively secrete excess extracellular matrix proteins like $\alpha$-SMA which is responsible for developing hepatic fibrosis. The expression of TGF- $\beta 1$ induced by $\alpha$-SMA is reduced once the p38 and JNK are inhibited by sugarcane polyphenol extract, therefore, sugarcane polyphenol extract can be considered as being effective in prevention of liver fibrosis (Wang et al., 2018).

\subsection{Flavonoids and associated bioactivity}

Studies have shown that sugarcane is a promising source of flavo- noids such as quercitrin, epicatechin, quercetin, catechin, isoquercitrin, rutin, naringenin, tricin, apigenin and luteolin derivatives (Figure 1 for structures) (Abbas et al., 2014; Joaquim et al., 2006; Pallavi et al., 2012). The highest flavonoid content was found in rind rather than other parts of sugarcane. Two various kinds of sugarcane with red and green rind were investigated for their flavonoid contents; the values were $408.62 \pm 15.92$ and $263.76 \pm 1.38$ $\mathrm{mg}$ rutin equivalents $/ 100 \mathrm{~g}$ dry weight, respectively (Feng et al., 2014). One study investigated the antioxidant potential and DNA damage protective activity of thirteen sugarcane cultivars, showing low concentration of sugarcane extract can significantly reduce DNA damage induced by hydroxyl radicals since flavonoids act as hydrogen donators and antioxidant agents. A flavonoid, tricin7-O- $\beta$-(6"-methoxycinnamic)-glucoside, was extracted from sugarcane juice and was proved to have a better antioxidant activity than trolox in the DPPH assay. It also had antiproliferative activity against several human cancer cell lines, especially in the multidrug resistant breast (NCI-ADR) cancer cell line (Duarte-Almeida et al., 2007).

Anthocyanins are another subclass of flavonoids that are always associated with colorful appearance and antioxidant activity in flowers, fruits and vegetables (Moyer et al., 2002). Intake of flavonoids/anthocyanins is associated with prevention of cardiovascular diseases, cancers and degenerative disorders (Kozlowska \& Szostak-Wegierek, 2014). Anthocyanins possess prominent antioxidant capacities such as superoxide anion scavenging activity and inhibition of lipoperoxidation in human erythrocytes (Ramirez et al., 2015). In addition to their anticancer activities (Bontempo et al., 2015; Zhao et al., 2004), anthocyanins showed anxiolytic and neuroprotective effects in an animal model (Gutierres et al., 2014) and exhibited potential in preventing Parkinson's and Alzheimer's diseases in animal and human models (Kim et al., 2010; Krikorian et al., 2010; Shih et al., 2010). In one study, Alzheimer's disease was induced in rats by scopolamine by lowering nitrite/nitrate $\left(\mathrm{NO}_{\mathrm{x}}\right)$ levels and $\mathrm{Na}^{+}, \mathrm{K}^{+}$-ATPase and $\mathrm{Ca}^{2+}$-ATPase and increasing acetylcholinesterase (AChE) activities in the cerebral cortex and hippocampus. Anthocyanins were able to prevent these altered effects significantly, showing cholinergic neurotransmission regulation and restore abnormal effects capabilities and prevention of memory impairment (Gutierres et al., 2014). Anthocyanins also showed stimulating insulin secretion, outstanding antihyperglycemic, HbAlc-decreasing activity and $\beta$-cell protective activity in pancreatic $\beta$-cell culture and db/db mice (Hong et al., 2013).

While peonidin-3-monogalactoside was found in sugarcane peel of Saccharum Officinarum in 1935, two anthocyanins, namely petunidin-3- $O$-(6"-succinyl)-rhamnoside and cyanidin-3- $O$-glucoside were first found in the peels of Chinese sugarcane S. sinensis using HPLC -UV/DAD and HPLC-MS/MS (Li et al., 2010). Researchers have also developed and used methods for extraction and determination of the total anthocyanins content (Li et al., 2011). One study used acidified methanol as a solvent to analyze anthocyanin, total flavonoid and total phenol contents of sugarcane peel as $0.00253,28.5$ and $136.12 \mathrm{mg} / \mathrm{g}$, respectively (Pallavi et al., 2012). Besides, for the first time, researchers concluded that sugarcane peel extracts were able to exert in vitro anti-proliferative activity against HT29 colon cancer cell line. The latest study of anthocyanins of sugarcane rind was done by Zhao et al. (2018). In 
<smiles>Oc1cc(O)c2c(c1)O[C@H](c1ccc(O)c(O)c1)[C@H](O)C2</smiles>

Epicatechin<smiles>O=c1cc(-c2ccc(O)cc2)oc2cc(O)cc(O)c12</smiles><smiles>COc1cc(-c2cc(=O)c3c(O)cc(O)cc3o2)cc(OC)c1O</smiles><smiles>CC1O[C@@H](Oc2c(-c3ccc(O)c(O)c3)oc3cc(O)cc(O)c3c2=O)[C@H](O)C(O)[C@@H]1O</smiles>

Quercitrin<smiles>Oc1cc(O)c2c(c1)O[C@H](c1ccc(O)c(O)c1)C(O)C2</smiles>

Catechin<smiles>O=c1cc(-c2ccc(O)c(O)c2)oc2cc(O)cc(O)c12</smiles><smiles>Oc1ccc([C@H]2CCc3c(O)cc(O)cc3O2)cc1</smiles>

Naringenin<smiles>O=c1c(O)c(-c2ccc(O)c(O)c2)oc2cc(O)cc(O)c12</smiles>

Quercetin

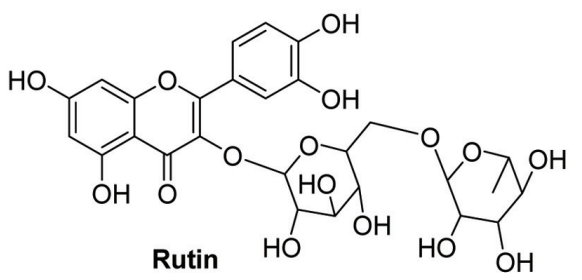<smiles>O=c1c(OC2OC3OC2C(O)C(O)C(O)C(O)C(O)C3O)c(-c2ccc(O)c(O)c2)oc2cc(O)cc(O)c12</smiles>

Isoquercitrin

Figure 1. Chemical structures of flavonoids from sugarcane rind.

the study, thirteen kinds of anthocyanins from three sugarcane cultivars were identified and quantified using ultra performance liquid chromatography (UPLC) with electrospray ionization quadrupoletime-of-flight tandem mass spectrometry (ESI-QTOF-MS/MS). Twelve anthocyanins were identified from sugarcane for the first time except cyandin-3-glucoside. The total anthocyanin content varied significantly from 10.8 to $132.0 \mu \mathrm{g} / \mathrm{g}$ dry rind weight. Antioxidant activities were determined by 2,2-diphenyl-1-picrylhydrazyl (DPPH), oxygen radical absorbance capacity (ORAC) and rapid peroxyl radical scavenging capacity (PSC) analysis, showing that red sugarcane rind had higher antioxidant activity than green sugarcane rind.

\subsection{Phenolic acids and associated bioactivities}

So far, there has been limited reports on the phenolic acid profiles of sugarcane rind. One study used a rapid ultrasonic-assisted extraction assay with HPLC to extract and quantify phenolic compounds from sugarcane rind, concluding that gallic acid, chlorogenic acid and ferulic acid were the three main phenolic components with high antioxidant ability (Feng et al., 2015b). The total phenolic content from rind extract was $302.50 \pm 19.50$ and 670.00 $\pm 17.00 \mathrm{mg} / \mathrm{g}$ using macro-porous resin adsorption and solvent ex- traction methods, respectively. The highest total phenolic content was found in the rind rather than the other parts.

As important components in human diet, phenolic acids have been researched for decades for their potential health benefits such as antioxidant, anti-inflammatory, antitumor, and antihistamine activities and reduced risk of cardiovascular diseases (Goleniowski et al., 2013). Caffeic acid as one of the most predominant natural cinnamic acids is known to possess antitumor ability against colon cancer, to impede biosynthesis of leukotrienes involved in asthma and immunoregulation diseases, and to act as an antihistamine against allergic reactions (Krupka \& Pelster, 1984; Olthof et al., 2001). Ferulic acid has low toxicity and can be absorbed and metabolized easily. Currently, ferulic acid is widely used in food and cosmetic industries for its physiological functions like antioxidant, antimicrobial, anti-inflammatory, anti-thrombosis and anticancer activities (Fujisawa, 2002; Hosoda et al., 2010). In addition, ferulic acid has potential benefits in the prevention of bone degeneration, hot flash symptoms in menopause, protection of skin from UV damage, and reducing serum LDL level (Lee et al., 1998). Gallic acid has impressive anticancer, anti-melanogenic and antivirus (HSV-2, herpes simplex virus) properties (Goleniowski et al., 2013; Kratz et al., 2008). Gallic acid exhibited ROS (reactive oxygen species)-mediated anticancer activity in human prostate cancer cells and induced death of HeLa cervical cancer 
<smiles>CC1(C)CCCC1(C)CO</smiles>

Policosanol

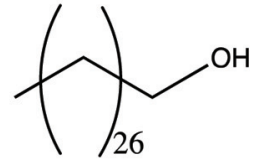

1-Octacosanol
Figure 2. Chemical structures of policosanol and 1-octacosanol.

cells by apoptosis and/or necrosis. Moreover, it had been reported to be involved in the treatment of brain tumor for its suppression of cell viability, proliferation, invasion and angiogenesis in human glioma cells (Luy et al., 2010; Wu et al., 2009).

\subsection{Long-chain fatty alcohols and associated bioactivities}

Policosanols, including 1-octacosanol (Figure 2), are generally extracted from sugarcane wax and have potential health benefits in lowering cholesterol, antiaggregatory properties, ergogenic properties and cytoprotective use (Taylor et al., 2003). Policosanol has been proven to lower hepatic and serum cholesterol levels by increasing HDL and decreasing LDL levels effectively in different animal studies (rats and monkeys) and clinical studies (Hargrove et al., 2004; Taylor et al., 2003). Policosanol is a more acceptable and effective substitute for statins as a normolipidemic agent without statin's typical side effects including muscle effects like myositis, headache, gastrointestinal effects, rash, angio-edema, altered liver function, and hepatitis (Castaño et al., 2000; Fernandez et al., 2001). Recent studies have further shown that dietary octacosanol can reduce plasma triacylglycerol levels in apoliproprotwin E-knockout mice (Xu et al., 2007). For anti-tumor activity, 1-octacosanol can control angiogenesis and metastasis via inhibition of matrix metalloproteinases (MMPs) and translocation of transcription factor nuclear factor NF- $\mathrm{KB}$ and then restraining of VEGF gene expression (Thippeswamy et al., 2008). Based on previous anti-tumor activity, lately, 1-octacosanol has been successfully incorporated in pharmaceuticals to improve the anti-tumor activity and eliminate toxicity of paclitaxel by acting as micellar carrier (Chu et al., 2016). Besides, studies have demonstrated that 1-octacosanol has anti-inflammatory and cytoprotective effects related to prostaglandin, thus, preventing ulceration and irritation (Carbajal et al., 1995; Carbajal et al., 1996). Since secretion of prostaglandin can protect gastric mucosa and further prevent ulceration and irritation, policosanol, unlike aspirin, may replace aspirin to protect against ischemic and thrombolytic events without interfering with prostaglandin production (Taylor et al., 2003).

Until now, different research efforts have extracted 1-OC from bagasse and press mud (Hou et al., 2007), but it is more convenient to directly extract it from sugarcane rind. Corresponding studies are shown in Table 2.

\subsection{Phytosterols and associated bioactivities}

Phytosterols have been extracted from sugarcane rind. Feng et al. (2014) demonstrated that the highest total sterol content was present in the rind rather than other parts. Red rind and green rind had total sterol content (TSC) of $438.71 \pm 28.62$ and $457.22 \pm 22.20$ $\mathrm{mg}$ phytosterol/100 g DW, respectively. Another study improved traditional solvent extraction with a combination of direct acid, alkaline saponification and HPLC analysis, successfully quantifying sterol content including steryl glycosides (SGs) and acylated steryl glycosides (ASGs) in sugarcane rind (Feng et al., 2015a). As a reference, traditional solvent extraction method failed to quantify SGs and ASGs easily. In this study, stigmasterol and $\beta$-sitosterol contents of green sugarcane rind cultivar were $848.3 \pm 29.7$ and $487.6 \pm 5.30 \mu \mathrm{g} / \mathrm{g}$ dry weight, while that of red sugarcane rind cultivar were $883.3 \pm 23.5$ and $663.4 \pm 32.4 \mu \mathrm{g} / \mathrm{g}$ dry weight, respectively (Feng et al., 2015a).

In general, phytosterols have two basic forms in plant tissues as free sterol and three conjugated sterols including steryl esters, steryl glycosides (SGs) and acylated steryl glycosides (ASGs) (Moreau et al., 2002). Phytosterols have been added in various conventional and functional foods and supplements marketed in many countries safely. No harmful side effects were reported among extensive toxicological studies and side-effects were comparable to placebo in clinical studies (Plat \& Mensink, 2001). Phytosterols are known to reduce cholesterol absorption and plasma LDL cholesterol level efficiently, so that phytosterols have potential in reducing the risk of coronary heart disease (Lin et al., 2011; Srigley \& Haile, 2015). Daily intake of 2-3 g of phytosterols can reduce LDL-cholesterol level by $10-15 \%$ (Plat \& Mensink, 2001). ASG has been proven to reduce plasma and liver cholesterol levels in mice by $86 \%$ or more four hours after gavage and to eventually reduce cholesterol absorption efficiency by $45 \pm 6 \%$ in a three-day fecal recovery study (Lin et al., 2011). One 2-weeks human study selected 11 healthy subjects to receive $300 \mathrm{mg}$ of added phytosterols (phytosterol glycosides, phytosterol esters or placebo) daily, concluding that phytosterol glycosides and phytosterol esters reduced cholesterol absorption by $37.6 \pm 4.8$ and $30.6 \pm 3.9 \%$, respectively, when compared with placebo test (Lin et al., 2009).

Besides, phytosterols are known to display anti-inflammation, anti-cancer and immunomodulatory properties (Awad \& Fink, 2000). Various studies have demonstrated that phytosterols were toxic to breast cancer, colon cancer and prostate cells (Feng et al., 2015a). An in vitro study showed that campesterol and $\beta$-sitosterol inhibited the growth of human prostate cancer PC-3 cells by 14 and $70 \%$, respectively; they also impeded PC-3 cells from disseminating effectively. In following in vivo study, diet containing $2 \%$ of phytosterols mixture resulted in $40-43 \%$ smaller tumors than that fed instead with cholesterol diet (Awad et al., 2001). Studies demonstrated that phytosterols had anti colon cancer effect (Awad et al., 1998; Rao \& Janezic, 1992), in which $\beta$-sitosterol at a dos-

Table 2. Method of 1-OC extraction from sugarcane rind

\begin{tabular}{|c|c|c|c|}
\hline Extraction methods & Conditions & 1-OC contents & References \\
\hline Supercritical $\mathrm{CO}_{2}$ extraction & Extracted for $4 \mathrm{~h}$ at $30 \mathrm{MPa}$ and at $45^{\circ} \mathrm{C}$. & $\begin{array}{l}53.14 \mathrm{mg} / \mathrm{g} \text { of sugarcane } \\
\text { skin on wet basis }\end{array}$ & (Yang et al., 2008) \\
\hline Supercritical $\mathrm{CO}_{2}$ extraction & $\begin{array}{l}\text { Extracted for } 4 \mathrm{~h} \text { at } 350 \text { bar and at } 50^{\circ} \mathrm{C} \text {, } \\
\text { with liquid } \mathrm{CO}_{2} \text { flow rate of } 40 \mathrm{~g} / \mathrm{min} \text {. }\end{array}$ & $1902.8 \pm 242.3 \mu \mathrm{g} / \mathrm{g}$ of dry plant ${ }^{\mathrm{a}}$ & (Attard et al., 2015) \\
\hline Anhydrous ethanol extraction & $\begin{array}{l}\text { Ethanol-sugarcane rind powder } 8: 1 \\
\mathrm{ml} / \mathrm{g} \text {, extracted for } 4 \mathrm{~h} \text { at } 80^{\circ} \mathrm{C} \text {. }\end{array}$ & $31 \mathrm{mg} / \mathrm{g}$ of crude sugarcane waxes & (Feng et al., 2015c) \\
\hline
\end{tabular}

${ }^{a}$ The value is expressed as the mean \pm SD of triplicate tests. 
age as $16 \mu \mathrm{M}$ for five days inhibited growth of HT-29 human colon cancer cells by activating the sphingomyelin cycle.

\subsection{Fibers and associated bioactivities}

Dietary fibers consist of two types of soluble and insoluble. Soluble fibers such as $\beta$-glucan can attenuate postprandial glycaemia/ insulinaemia and lower serum LDL cholesterol level (Jones, 2013; Mudgil \& Barak, 2013), reduce body weight gain, suppress excessive accumulation of white adipose tissue (WAT) and increase energy expenditure (Wang et al., 2018), while insoluble fibers can increase fecal bulk/laxation and stimulate colonic fermentation (Fernandez \& Borroto, 1996; Fuller et al., 2016). In a 60,000 persons 4-year follow up study, higher long-term intake of dietary fiber ( $25 \mathrm{~g}$ /day) was associated with decreased risk of fecal incontinence in older women with mean age 73 and also liquid stool FI by 18 and $31 \%$ than that of lower quantity fiber intake ( $13.5 \mathrm{~g} /$ day) (Staller et al., 2018).

Additionally, dietary fibers have potential in lowering the risk of ovarian cancer (Xu et al., 2018), coronary heart disease and cardiovascular aliment (Mcrae, 2017). Sugarcane bagasse acts as a lignocellulosic material and consists of soluble fiber (20-25\% hemicellulose) and insoluble fibers (45-55\% cellulose and 18 24\% lignin) (Reddy \& Yang, 2016).

A multicenter, randomized, double blind and placebo-controlled trial was conducted to investigate sugarcane bagasse dietary fiber (SBDF) as an adjuvant therapy for stable chronic obstructive pulmonary disease. In total, 196 participants were treated with $6 \mathrm{~g}$ of SBDF daily for 30 days and a 6-month follow-up. Post-treatment pulmonary clinical symptoms and severity of dyspnea were significantly relieved in trail group, besides, better results showed in St. George's Respiratory Questionnaire for trial group compared to the control group (Miao et al., 2016).

Sugarcane dietary fiber (SDF) has been researched in various food products for different reasons. SDF was added to replace fat in meat products like frankfurter containing 30\% animal fat with high content of cholesterol and saturated fat unfavorable by customers (Zhuang et al., 2016). In this way, actual usage of SDF indirectly lowered the risk of obesity, hypertension, coronary heart and cardiovascular diseases. SDF has been added in baked food contributed to its neutral in taste and odor, in which SDF was treated with alkaline hydrogen peroxide (AHP) to improve its physical and chemical properties. AHP treatment removed 53\% of lignin and increased water capacity and oil-binding capacity by 96 and $55 \%$, respectively. As a result, addition of $10 \%$ AHP-treated SDF and $1.5 \%$ sucrose ester in bread enriched nutraceutical components and maintained good customer acceptance (Sangnark \& Noomhorm, 2003).

\section{Summary}

Sugarcane rind has valuable phytochemicals including various flavonoids, phenolic acids, octacosanol, phytosterols and dietary fiber. These components can provide vital health benefits such as antioxidant, anti-inflammatory, anticancer, antivirus and further attenuation of the risk of cardiovascular and coronary heart disease. As a disposed part in sugarcane industry, effective extraction of these phytochemicals from sugarcane rind is a double-win strategy. However, optimum extraction method of each phytochemical or a thoughtful entire extraction process of several or all phytochemicals still needs to be investigated. Furthermore, relatively few research has focused on health benefits of sugarcane rind and further studies are required to confirm the actual mechanism behind the associated health benefits.

\section{References}

Abbas, S.R., Sabir, S.M., Ahmad, S.D., Boligon, A.A., and Athayde, M.L. (2014). Phenolic profile, antioxidant potential and DNA damage protecting activity of sugarcane (Saccharum officinarum). Food Chem. 147: 10-16.

AG, Australian Government. (2011). The biology of the Saccharum spp. (Sugarcane).

Allen, C.J., Mackay, M.J., Aylward, J.H., and Campbell, J.A. (1997). New technologies for sugar milling and by-product modification. Intensive Sugarcane Production: Meeting the Challenges Beyond 2000 In: Keating, BA, and Wilson, JR (Ed.). CAB International Wallingford, UK, 267-285.

Ashade, O.O., Abubakar, R.O., Nguka, O.O., Yakubu, A.O., Oyesanta, O., Ofoegbu, C.C., Bello, O.N., and Osuntade, B.A. (2014). Impact of sugarcane peel (Saccharum Officinarum) extract on the blood status and gonadal integrity of Wistar Albino rat. Int. J. Adv. Pharm. Bio. Chem. 3(3): 646-655.

Attard, T.M., Mcelroy, C., Rezende, C.A., Polikarpov, I., Clark, J.H., and Hunt, A.J. (2015). Sugarcane waste as a valuable source of lipophilic molecules. Ind. Crops Prod. 76: 95-103.

Awad, A.B., and Fink, C.S. (2000). Phytosterols as anticancer dietary components: evidence and mechanism of action. J. Nutr. 130(9): 21272130.

Awad, A.B., Fink, C.S., Williams, H., and Kim, U. (2001). In vitro and in vivo (SCID mice) effects of phytosterols on the growth and dissemination of human prostate cancer PC-3 cells. Eur. J. Cancer Prev. 10(6): 507-513.

Awad, A.B., Von Holtz, R.L., Cone, J.P., Fink, C.S., and Chen, Y.C. (1998). Beta-sitosterol inhibits growth of HT-29 human colon cancer cells by activating sphingomyelin cycle. Anticancer Res. 18(1A): 471-3.

Bahadoran, Z., Mirmiran, P., and Azizi, F. (2013). Dietary polyphenols as potential nutraceuticals in management of diabetes: a review. J. Diabetes Metab. Disord. 12(1): 43.

Bontempo, P., Masi, L.D., Carafa, V., Rigano, D., Scisciola, L., Iside, C., and Altucci, L. (2015). Anticancer activities of anthocyanin extract from genotyped Solanum tuberosum L. "Vitelotte". J. Funct. Foods 19: 584-593.

Bucio-Noble, D., Kautto, L., Krisp, C., Ball, M.S., and Molloy, M.P. (2018). Polyphenol extracts from dried sugarcane inhibit inflammatory mediators in an in vitro colon cancer model. J. Proteom. 177: 1-10.

Carbajal, D., Molina, V., Valdés, S., Arruzazabala, L., and Más, R. (1995). Anti-ulcer activity of higher primary alcohols of beeswax. J. Pharm. Pharmacol. 47(9): 731-733.

Carbajal, D., Molina, V., Valdés, S., Arruzazabala, L., Rodeiro, I., Más, R., and Magraner, J. (1996). Possible cytoprotective mechanism in rats of D-002, an anti-ulcerogenic product isolated from beeswax. Pharm. Pharmacol. 48(8): 858-860.

Castaño, G., Más, R., Arruzabala, M.D., Noa, M., Illnait, J., Fernández, J., and Menéndez, A. (2000). Effects of policosanol and pravastatin on lipid profile, platelet aggregation and endothelemia in older hypercholesterolemic patients. Atherosclerosis 151(1): 314.

Chu, B., Qu, Y., Huang, Y., Zhang, L., Chen, X., Long, C., and Qian, Z. (2016). PEG-derivatized octacosanol as micellar carrier for paclitaxel delivery. Int. J. Pharm. 500(1-2): 345-359.

DAFFRSA, Department of Agriculture, Forestry and Fisheries of Republic of South Africa. (2014). Sugarcane production guideline.

Duarte-Almeida, J.M., Negri, G., Salatino, A., Carvalho, J.E., and Lajolo, F.M. (2007). Antiproliferative and antioxidant activities of a tricin acylated glycoside from sugarcane (Saccharum officinarum) juice. Phytochem. 68(8): 1165-1171.

Feng, S., Luo, Z., Zhang, Y., Zhong, Z., and Lu, B. (2014). Phytochemical contents and antioxidant capacities of different parts of two sugarcane (Saccharum OfficinarumL.) cultivars. Food Chem. 151: 452-458.

Feng, S., Liu, S., Luo, Z., and Tang, K. (2015a). Direct saponification preparation and analysis of free and conjugated phytosterols in sugarcane 
(Saccharum OfficinarumL.) by reversed-phase high-performance liquid chromatography. Food Chem. 181: 9-14.

Feng, S., Luo, Z., Tao, B., and Chen, C. (2015b). Ultrasonic-assisted extraction and purification of phenolic compounds from sugarcane (Saccharum officinarum L.) rinds. LWT - Food Sci. Technol. 60(2): 970-976.

Feng, S., Luo, Z., Zeng, F., Liu, S., and Khan, Z.U. (2015c). Effect of water, metallic ions, fatty acid and temperature on oxidative stability of 1-octacosanol from sugarcane rind. Food Chem. 182: 171-177.

Fernandez, J., Mas, R., Castano, G., Menandez, R., Amor, A., Gonzalez, R., and Alvarez, E. (2001). Comparison of the efficacy, safety and tolerability of policosanol versus Fluvastatin in elderly hypercholesterolaemic women. Clin. Drug Investig. 21(2): 103-113.

Fernandez, M., and Borroto, B. (1996). Dietary fibre from cane bagasse: a new alternative for use of these residues. Alimentaria 277: 37-38.

Fujisawa, S. (2002). Antioxidant and prooxidant action of eugenol-related compounds and their cytotoxicity. Toxicology 177(1): 39-54.

Fuller, S., Beck, E., Salman, H., and Tapsell, L. (2016). New horizons for the study of dietary fiber and health: a review. Plant Foods Hum. Nutr. 71(1): 1-12.

Georges, P., Sylvestre, M., Ruegger, H., and Bourgeois, P. (2006). Ketosteroids and hydroxyketosteroids, minor metabolites of sugarcane wax. Steroids 71(8): 647-652.

Goleniowski, M., Bonfill, M., Cusido, R., and Palazón, J. (2013). Phenolic acids. Natural Products 1951-1973.

Gutierres, J.M., Carvalho, F.B., Schetinger, M.R., Agostinho, P., Marisco, P.C., Vieira, J.M., and Mazzanti, C.M. (2014). Neuroprotective effect of anthocyanins on acetylcholinesterase activity and attenuation of scopolamine-induced amnesia in rats. Int. J. Dev. Neurosci. 33: 88-97.

Hanamura, T., Mayama, C., Aoki, H., Hirayama, Y., and Shimizu, M. (2006). Antihyperglycemic effect of polyphenols from acerola (Malpighia emarginata DC.) fruit. Biosci. Biotechnol. Biochem. 70(8): 1813-1820.

Hargrove, J.L., Greenspan, P., and Hartle, D.K. (2004). Nutritional significance and metabolism of very long chain fatty alcohols and acids from dietary waxes. Exp. Bio. Med. 229: 215-226.

Hong, S.H., Heo, J., Kim, J., Kwon, S., Yeo, K., Bakowska-Barczak, A.M., and Lee, J. (2013). Antidiabetic and beta cell-protection activities of purple corn anthocyanins. Biomol. Ther. 21(4): 284-289.

Hosoda, A., Ozaki, Y., Kashiwada, A., Mutoh, M., Wakabayashi, K., Mizuno, K., and Taniguchi, H. (2002). Syntheses of ferulic acid derivatives and their suppressive effects on cyclooxygenase-2-promoter activity. Bioorg Med Chem. 10(4): 1189-1196.

Hou, Z.F., Deng, D.W., Zhang, B., and Zhou, W. (2007). Extraction and purification of 1-octacosanol from sugarcane wax. Food Ferment. Ind. 2: 82.

Inarkar, M.B., and Lele, S.S. (2012). Extraction and characterization of sugarcane peel wax. ISRN Agronomy 2012: 1-6.

Iwai, K. (2008). Antidiabetic and antioxidant effects of polyphenols in brown alga ecklonia stolonifera in genetically diabetic KK-Ay mice. Plant Foods Hum. Nutr. 63(4): 163-169.

Joaquim, M.D.A., Maurício, D.V.N., Adyary, F.L., Franco, M.L., and Maria, I.G. (2006). Antioxidant activity of phenolic compounds from sugar cane (Saccharum officanarum L.) juice. Plant Foods Hum. Nutr. 61: 187-192.

Jones, J.M. (2013). Dietary fiber future directions: integrating new definitions and findings to inform nutrition research and communication12. Adv. Nutr. 4(1): 8-15.

Kim, H.G., Ju, M.S., Shim, J.S., Kim, M.C., Lee, S.H., Huh, Y., Kim, S.Y., and Oh, M.S. (2010). Mulberry fruit protects dopaminergic neurons in toxin-induced Parkinson's disease models. Brit. J. Nutr. 104: 8-16.

Kozlowska, A., and Szostak-Wegierek, D. (2014). Flavonoids: food sources and health benefits. Rocz. Państw. Zakł. Hig. 65: 79-85.

Kratz, J.M., Andrighetti-Fröhner, C.R., Leal, P.C., Nunes, R.J., Yunes, R.A., Trybala, E., and Simões, C.M. (2008). Evaluation of anti-HSV-2 activity of gallic acid and pentyl gallate. Biol Pharm Bull. 31(5): 903-907.

Krikorian, R., Shidler, M.D., Nash, T.A., Kalt, W., Vinqvist-Tymchuk, M.R., Shukitt-Hale, B., and Joseph, J.A. (2010). Blueberry supplementation improves memory in older adults. J. Agric. Food Chem. 58: 39964000.

Krupka, U., and Pelster, B. (1984). Inhibition of leukotriene B4 biosynthesis by a novel phosphodiesterase inhibitor. Prostaglandins 28(5): 639.
Lee, S.K., Mbwambo, Z.H., Chung, H.S., Luyengi, L., Games, E.J.C., and Mehta, R.G. (1998). Evaluation of the antioxidant potential of natural products. Comb. Chem. High Throughput Screen. (1): 35-46.

Lin, X., Ma, L., Moreau, R.A., and Ostlund, R.E. (2011). Glycosidic bond cleavage is not required for phytosteryl glycoside-induced reduction of cholesterol absorption in mice. Lipids 46(8): 701-708.

Lin, X., Ma, L., Racette, S.B., Spearie, C.L., and Ostlund, R.E. (2009). Phytosterol glycosides reduce cholesterol absorption in humans. Am. J. Physiol. Gastrointest. Liver Physiol. 296(4): G931-G935.

Li, X., Song, H., Yao, S., Jia, C., Yang, Y., and Zhu, W. (2011). Quantitative analysis and recovery optimization of flavonoids and anthocyanins in sugar-making process of sugarcane industry. Food Chem. 125: 150-157.

Li, X., Yao, S., Tu, B., Li, X., Jia, C., and Song, H. (2010). Determination and comparison of flavonoids and anthocyanins in Chinese sugarcane tips, stems, roots and leaves. J. Sep. Sci. 33(9): 1216-1223.

Luy, J.F., Jiang, H., Wu, K., Zheng, X., Cai, Y., Katakowski, M., and Chopp, M. (2010). Effects of mixtures of phenolic acids on phosphorus uptake by cucumber seedlings. Eur. J. Pharmacol. 641: 102.

Mcrae, M.P. (2017). Dietary fiber is beneficial for the prevention of cardiovascular disease: an umbrella review of meta-analyses. J. Chiropr. Med. 16(4): 289-299.

Miao, L., Fengjie, Z., Lei, N., Yan, S., Ruohan, W., Tianyu, Z., and Yuhang, L. (2016). Sugarcane bagasse dietary fiber as an adjuvant therapy for stable chronic obstructive pulmonary disease: a four-center, randomized, double-blind, placebo-controlled study. J. Tradit. Chin. Med. 36(4): 418-426.

Moreau, R.A., Whitaker, B.D., and Hicks, K.B. (2002). Phytosterols, phytostanols, and their conjugates in foods: Structural diversity, quantitative analysis, and health- promoting uses. Prog. Lipid Res. 41(6): 457-500.

Moyer, R.A., Hummer, K.E., Finn, C.E., Frei, B., and Wrolstad, R.E. (2002) Anthocyanins, phenolics, and antioxidant capacity in diverse small fruits, Vaccinium, Rubus, and Ribes. J. Agric. Food Chem. 50: 519525.

Mudgil, D., and Barak, S. (2013). Composition, properties and health benefits of indigestible carbohydrate polymers as dietary fiber: a review. Int J. Bio. Macromol. 61: 1-6.

Nair, N.V. (2009). Sugarcane agriculture and sugar industry current scenario and future prospect. International Training on Breeding Sugarcane for Sugar-Industrial Complex Sugarcane Breeding Institute, Coimabtore, 12-16.

Olthof, M.R., Hollman, P.C., and Katan, M.B. (2001). Chlorogenic acid and caffeic acid are absorbed in humans. J. Nutr. 131(1): 66-71.

Pallavi, R., Elakkiya, S., Tennety, S.S.R., and Devi, P.S. (2012). Anthocyanin analysis and its anticancer property from sugarcane (Saccharum Officinarum L.) peel. Int. J. Res. Pharm. Chem. 2(2): 338-345.

Partha, N., and Sivasubramanian, V. (2006). Recovery of chemicals from press mud a sugar industry waste. Indian Chem. Eng., Sect A. 48(3): 160-163.

Pietta, P., Minoggio, M., and Bramati, L. (2003). Plant polyphenols: structure, occurrence and bioactivity. Nat. Prod. Chem. 28: 257-312.

Plat, J., and Mensink, R.P. (2001). Effects of plant sterols and stanols on lipid metabolism and cardiovascular risk. Nutr. Metab. Cardiovasc Dis. 11(1): $31-40$

Ramirez, J.E., Zambrano, R., Sepúlveda, B., Kennelly, E.J., and Simirgiotis, M.J. (2015). Anthocyanins and antioxidant capacities of six Chilean berries by HPLC-HR-ESI-ToF-MS. Food Chem. 176: 106-114.

Rao, A.V., and Janezic, S.A. (1992). The role of dietary phytosterols in colon carcinogenesis. Nutr. Cancer 18(1): 43-52.

Reddy, N., and Yang, Y. (2016). Fibers from sugarcane bagasse. Innovative Biofibers from Renewable Resources Springer, Berlin, Heidelberg, 29-30.

Sangnark, A., and Noomhorm, A. (2003). Effect of particle sizes on functional properties of dietary fiber prepared from sugarcane bagasse. Food Chem. 80(2): 221-229.

Shih, P.H., Chan, Y.C., Liao, J.W., Wang, M.F., and Yen, G.C. (2010). Antioxidant and cognitive promotion effects of anthocyanin-rich mulberry (Morus atropurpurea L.) on senescence-accelerated mice and prevention of Alzheimer's disease. J. Nutr. Biochem. 21: 598-605.

Songsermpong, S., and ljttanit, W. (2010). Comparison of peeling, squeez- 
ing and concentration methods for the sugarcane juice production. Suranaree J. Sci. Technol. 17(1): 49-55.

Srigley, C.T., and Haile, E.A. (2015). Quantification of plant sterols/stanols in foods and dietary supplements containing added phytosterols. J. Food Compost. Anal. 40: 163-176.

Staller, K., Song, M., Grodstein, F., Whitehead, W.E., Matthews, C.A., Kuo, B., and Chan, A.T. (2018). Increased long-term dietary fiber Intake is associated with decreased risk of fecal incontinence in older women. Gastroenterology 155(3): 661-667, e1. doi:10.1053/j.gastro.2018.05.021.

Taylor, J.C., Rapport, L., and Lockwood, G.B. (2003). Octacosanol in human health. Nutrition 19(2): 192-195.

Thippeswamy, G., Sheela, M., and Salimath, B.P. (2008). Octacosanol isolated from Tinospora cordifolia downregulates VEGF gene expression by inhibiting nuclear translocation of NF-B and its DNA binding activity. Eur. J. Pharmacol. 588(2-3): 141-150.

USDA, United States Department of Agriculture. (2017). Sugar: world markets and trades.

Wang, H., Hong, T., Li, N., Zang, B., and Wu, X. (2018). Soluble dietary fiber improves energy homeostasis in obese mice by remodeling the gut microbiota. Biochem. Biophys. Res. Commun. 498(1): 146-151.

Wang, L., Pan, M.H., Lo, C.Y., Zhao, H., Li, S., Ho, C.T., and Yang, G. (2018). Anti-fibrotic activity of polyphenol-enriched sugarcane extract in rats via inhibition of p38 and JNK phosphorylation. Food Funct. 9(2):
951-958.

Wu, J., Jan, P., Yu, H., Haung, H., Fang, H., Chang, Y., and Chen, H.M. (2009). Structure and function of a custom anticancer peptide, CB1a. Peptides 30(5): 839-848.

Xu, H., Ding, Y., Xin, X., Wang, W., and Zhang, D. (2018). Dietary fiber intake is associated with a reduced risk of ovarian cancer: A dose-response meta-analysis. Nutr. Res. 57: 1-11.

Xu, Z., Fitz, E., Riediger, N., and Moghadasian, M.H. (2007). Dietary octacosanol reduces plasma triacylglycerol levels but not atherogenesis in apolipoprotein E-knockout mice. Nutr. Res. 27(4): 212-217.

Yang, H.Q., Chang, Y.Z., and Wu, F.H. (2008). Study on supercritical extraction of 1-octacosano from sugarcane skin. Food Sci. Technol. .

Zhao, C., Giusti, M.M., Malik, M., Moyer, M.P., and Magnuson, B.A. (2004). Effects of commercial anthocyanin-rich extracts on colonic cancer and nontumorigenic colonic cell growth. J. Agric. Food Chem. 52(20): 6122-6128.

Zhao, Z., Yan, H., Zheng, R., Khan, M.S., Fu, X., Tao, Z., and Zhang, Z. (2018). Anthocyanins characterization and antioxidant activities of sugarcane (Saccharum Officinarum L.) rind extracts. Ind. Crops and Prod. 113: 38-45.

Zhuang, X., Han, M., Kang, Z., Wang, K., Bai, Y., Xu, X., and Zhou, G. (2016) Effects of the sugarcane dietary fiber and pre-emulsified sesame oil on low-fat meat batter physicochemical property, texture, and microstructure. Meat Sci. 113: 107-115. 